\title{
Occupational Gender Segregation in Turkey: The Vertical and Horizontal Dimensions
}

\author{
Cigdem Gedikli ${ }^{1}$ (D)
}

Published online: 10 December 2019

(c) The Author(s) 2019

\begin{abstract}
This paper investigated occupational gender segregation and its vertical and horizontal dimensions in Turkey. In order to explore the extent of inequality entailed in occupational gender segregation (measured by the vertical dimension), average pay levels across occupations were used. In addition to the economic inequalities captured by pay, aiming to explore the social inequalities inherent in occupational segregation, Cambridge Social Interaction and Stratification Scale scores across occupations were used. The results showed that the extent of inequality associated with occupational gender segregation was substantial, operating to the detriment of women. Women were more likely to be employed in lower-paid jobs and in occupations that ranked lower across the overall stratification structure, while men remained at an advantaged position in terms of both the pay levels and the positions of the occupations they held in the social hierarchy.
\end{abstract}

Keywords Gender · Occupational segregation · Inequality · Pay · Social stratification · Turkey

\section{Introduction}

Although family structures and social values are changing and challenging the male breadwinner norm, evidence based on time-use or equivalent surveys shows that women continue to allocate more time to unpaid domestic work than do men (Kan 2008; Sevilla-Sanz et al. 2010). Women across the world leave their jobs upon marriage or having children, or they move into lower-paid and lower-status, mostly part-time jobs upon their return to employment after motherhood (Connolly and Gregory 2008). This translates into a segregated workforce, with women typically engaging in clerical and service work and with men dominating the production and managerial occupations (Anker et al. 2003; Charles 1990). Regardless of the level of economic development, it seems that there is a degree of occupational segregation. However, the extent varies across countries, depending mainly on the structure of the post-industrial economy (for example, the size of the service sector and the prevalence of part-time employment and flexible working conditions) and on the shift from traditional to more egalitarian norms and

Cigdem Gedikli

cigdem.gedikli@swansea.ac.uk

1 School of Management, Swansea University, Bay Campus, Fabian Way, Swansea SA1 8EN, UK cultural attitudes towards women and employment (Bettio and Verashchagina 2009; Charles 2003; Dolado et al. 2003).

This paper investigates occupational gender segregation using data for Turkey and building on the longstanding interest in exploring the inequality associated with women's segregation into certain occupations. Shifting from unidimensional index measures such as the index of dissimilarity (ID) (Duncan and Duncan 1955) or the Karmel MacLachlan Index (IP) (Karmel and MacLachlan 1988) to a multidimensional approach, the research analyzed segregation and inequality separately and differentiated between the horizontal and vertical components of segregation (Blackburn et al. 2001; Blackburn 2009; Charles 2003; Semuonov and Jones 1999). Accordingly, horizontal segregation was defined as the extent to which women and men were employed in different occupations (sometimes referred to as "distributional inequality", Charles 2003, p. 268). Vertical segregation, on the other hand, indicated the relative position of women (for example, in terms of pay or level of social status) across the occupational hierarchy.

The differentiation between vertical and horizontal segregation was helpful in explaining cross-country variations in occupational gender segregation as well as the surprisingly high segregation figures for relatively more gender-egalitarian countries. For example, the higher segregation levels in Scandinavian countries as compared to those in Italy, 
Portugal, or Spain, which are known to remain traditional with respect to gender roles, were shown to owe more to the difference in the occupational distributions of women and men (horizontal segregation) rather than to women being employed in occupations that are less prestigious or less rewarding in terms of pay (vertical segregation). In terms of vertical segregation, studies have even noted that women started having a greater tendency to hold more prestigious and high-status occupations than did men in Scandinavian countries, Germany, the USA, and Britain, although men continued to have an advantage in terms of pay levels (for example, see Blackburn et al. 2001; Jarman et al. 2012). This was attributed to the shift from manual to non-manual work and the expansion of the service sector, which brought more women to professional employment with better occupational standing, alongside the promotion of gender-equal norms and policies enabling couples to share domestic work and caring responsibilities (Charles 2003; Jarman et al. 2012).

Whilst the evidence coming mostly from developed countries provides valuable insights into the factors leading to progress towards a more gender-equal occupational structure, we know less about the occupational gender segregation and its vertical and horizontal dimensions in countries where social and structural changes have not necessarily favored women's employment. Rather, they arguably have resulted in limited employment opportunities for women or in greater gender discrimination against them in terms of lower returns to their labor market characteristics (Elson 1999). Structural transformation away from manufacturing to services is not realized across all countries to the same extent, and traditionalism towards the division of labor and the classic male breadwinner norm remains in effect. Exploring occupational gender segregation in Turkey is, therefore, particularly important for documenting the strength of these dynamics and providing an indirect comparison with the rest of the world in terms of their contribution to a segregated workforce.

\section{Background}

Amongst many demand- and supply-side-related changes, structural transformation-particularly, the rise of the service sector-has been noted as one of the most pronounced factors bringing about a sustained increase in women's employment in developed countries (see Akbulut 2011; Fan and Lui 2003; Ngai and Petrongolo, 2017; Olivetti and Petrongolo 2014; Rendall 2018). ${ }^{1}$ Whilst structural

\footnotetext{
${ }^{1}$ Research into economic growth defined the process of structural transformation as the move of labor across three major sectors of employment: agriculture, manufacturing, and services. The process is typically characterized by a continuous fall in the share of agriculture in total employment, a hump-shaped pattern in manufacturing (its
}

transformation provided service-sector jobs in which women had a comparative advantage, the marketization of home production further allowed them to allocate more time to market work (Greenwood et al. 2005; Ngai and Petrongolo 2017). Given that manufacturing production was relatively intensive in the use of brawn, whereas services production was relatively intensive in the use of the brain, the historical growth in services created a labor demand which was biased towards female labor, as women had an innate comparative advantage in terms of brain (Galor and Weil 1996; Rendall 2018). This growth in services coincided with significant improvements in women's educational qualifications, their access to and use of contraceptives, and declining fertility rates, which resulted in women's increased representation in the white-collar sector-mainly in clerical jobs, for which they received better pay and enjoyed better working conditions than they would have if they had worked at jobs in factories (Goldin 1995, 2006; Heathcote et al. 2010). In parallel, social progress towards more egalitarian attitudes towards women and work, as well as policies aimed at providing a better work-family balance and a more equal division of paid and unpaid work, brought more women to professional employment, with better social and economic returns (Goldin 2006; Razavi et al. 2012).

Nevertheless, countries differ in terms of their levels of economic development and the accompanying move away from agriculture to manufacturing and, eventually, to services. The international variation in the extent of the shift across sectors and the underlying changes in the industrial structure contributed to the noteworthy differences in women's positions across the labor markets and was responsible for a large portion of gender gaps in market hours and wages across countries (Mehra and Gammage 1999; Olivetti and Petrongolo 2014, 2017). Additionally, country-specific elements such as economic development strategies, the institutional framework, parental leave policies, and attitudes towards women's employment had an important effect on the extent of the expansion in services and the ways in which it influenced women's employment. Given these facts, it is not surprising that whilst the service sector was associated with increased female employment rates and reduced gender wage gaps in developed countries, the changes in the industrial structure and the expansion of certain industries, including services, did not always produce equally positive occupational outcomes for women across all countries.

For example, although the rise in the production of exports provided new forms of employment for women in

\footnotetext{
Footnote 1 (continued)

share increasing during the early phases of economic development and then declining as countries' income levels rise), and a steady rise
} in services. 
export-manufacturing in developing countries, the motivation behind the increased demand for a female workforce was women's lower wages (for example, see Berik et al. 2004 for Taiwan and Korea and Menon and Rodgers 2009 for the Indian manufacturing industry). This was reflected in the form of stronger occupational segregation, with women being segregated into seasonal/temporary jobs with low pay and unsatisfactory working conditions, while men secured the few permanent jobs in these sectors (Razavi et al. 2012). In addition to the pursuit of cheap labor as a source of international competitiveness, further developments accompanied by globalization - such as financial liberalization, and the downsizing and privatization of the public sector-all had some adverse outcomes for women, such as a rise in the informal sector and a greater incidence of precarious and atypical forms of employment which were filled mostly by women not only in developing but also in developed countries (Standing 1999). Likewise, although it brought about improvements in women's occupational outcomes, a large service sector also implied the incorporation of traditionally female tasks - such as caring, food services, weaving, or making clothes-into the formal economy (Charles 1992; Mandel and Semyonov 2006).

Similar opposing arguments were also made for the situation of women in the public sector. Whilst it provided a source of protection for women and brought about better opportunities than the private sector did in terms of access to highly ranked occupations (for example, in corporate managers or even in male-dominated occupations such as engineering), the public sector was also associated with women's concentration into typically female occupations, including caring activities (Burchell et al. 2014; Emerek et al. 2003). ${ }^{2}$ In this regard, it was argued that the same structural transformations that reduced the gender gap in the labor force produced a deepening institutionalization of gender across occupations (Charles 1992). Perhaps this explains the persistent horizontal segregation figures even in developed countries.

Despite the improvements, the gendered division of responsibilities is still deeply embedded in societies and influences women's employment directly and indirectly by affecting the factors that shape the industrial structure, the labor markets, and the positions of women within them. The gendered constraints/barriers that men and women face throughout their lives affect their access to resources and educational choices and also reinforce gender stereotypes

\footnotetext{
${ }^{2}$ It was also argued that encouraging women's segregation into public sector employment to protect them from discriminatory practices in the private sector actually reduced their career opportunities and their representation in high-status occupations in the private sector (Mandel and Semyonov 2006).
}

in occupational outcomes (Seron et al. 2016). Norms and legal/institutional elements that are shaped within the constraints of traditional gender roles, as well as the degree to which they tolerate or promote gender-discriminatory practices, prevent women from entering certain occupations or limit their ability to freely choose occupations (Charles 2003; Rubery and Fagan 1995). Indeed, preferences for certain occupations (for example, the tendency for women to choose flexible or family-friendly occupations) might be the consequences of cultural expectations that attribute housework and childcare primarily to women (Devine 1994; Hesmondhalgh and Baker 2015). In parallel, the sex-biased preferences of employers and the act of re-labeling jobs as "female" could result in a deterioration of pay or prestige, as well as of the attractiveness of feminized occupations which men used to dominate (Reskin and Roos 1990; Standing 1999).

That is to say, occupational gender segregation is complex, and increasing women's labor market participation is not a straightforward path to creating an occupational structure that is less segregated by gender. This paper has commented upon these elements by providing a detailed descriptive investigation of occupational gender segregation in Turkey and the degree to which women have been segregated into less rewarding occupations. Following the approach suggested by Blackburn et al. (2001), it investigated the overall difference in the distribution of men and women across occupations (overall occupational segregation) and the inequality inherent in this pattern in terms of different occupational outcomes between them (vertical segregation). In this context, horizontal dimension referred to the residual difference in the distribution of men and women across occupations once the inequality in terms of a vertical criterion was taken into account.

Conventionally, occupations were valued according to their economic and labor market characteristics, such as pay or skill level, which eventually transformed into earnings (Bottero 2005). The vertical dimension of segregation was, therefore, captured by ranking occupational groups according to average levels of pay-a method also employed in this paper. However, although income generated from employment is the main source of economic rewards, it is important to evaluate the meaning of holding an occupation in a wider context and to acknowledge the social rewards associated with employment. Occupations can play a significant role in structuring the social space and, thereby, can create or hinder pathways to social networks and opportunities (Stewart et al. 1980). These are crucial aspects for gaining a full understanding of female employment for policymaking. Therefore, to capture the inequalities between women and men, the ranking should be sensitive to the locations of the occupations in the social hierarchy. To achieve this, the Cambridge Social 
Table 1 Key national statistics

\begin{tabular}{|c|c|c|c|c|c|c|c|c|c|}
\hline & \multicolumn{2}{|c|}{$\begin{array}{l}\text { Illiterate/no } \\
\text { diploma }\end{array}$} & \multicolumn{2}{|c|}{ Higher education } & \multirow[t]{2}{*}{ Fertility rates } & \multicolumn{2}{|c|}{$\begin{array}{l}\text { Labour force par- } \\
\text { ticipation rates }\end{array}$} & \multicolumn{2}{|c|}{ Employment rates } \\
\hline & Women & Men & Women & Men & & Women & Men & Women & Men \\
\hline 1980 & 67.97 & 35.55 & 1.56 & 8.85 & 3.41 & 45.8 & 79.8 & & \\
\hline 1990 & 45.80 & 18.88 & 2.83 & 7.32 & 2.65 & 35.3 & 80.5 & 32.6 & 74.6 \\
\hline 2000 & 34.89 & 12.28 & 5.39 & 10.23 & 2.53 & 26.6 & 73.7 & 24.9 & 68.9 \\
\hline 2010 & 20.95 & 7.00 & 8.63 & 13.28 & 2.06 & 27.6 & 70.8 & 24.0 & 62.7 \\
\hline 2018 & 15.37 & 4.03 & 17.37 & 22.17 & 1.99 & 38.32 & 78.58 & 32.89 & 70.92 \\
\hline
\end{tabular}

Source: TurkStat: Census of Population; National Education Statistics Database; General Directorate of Civil Registration and Nationality; Labor Force Statistics. Retrieved from https://www.turkstat.gov.tr/ UstMenu.do?metod=kategorist. Note: Two-digit figures were not available for some years.

Interaction and Stratification Scales (CAMSIS) for Turkey were used (see Gedikli and Gedikli 2014; Lambert and Prandy 2018). The CAMSIS scales are conceptualized as "social interaction distance scales" and are regarded broadly as an indicator of general social or material advantage, social hierarchy, prestige, and social status (Blackburn and Jarman 2006, p. 301). ${ }^{3}$

\section{An Overview of the Labor Market in Turkey and Occupational Gender Segregation}

Despite economic growth, significant improvements in women's educational qualifications, and declining fertility rates, the employment rates of women have actually fallen in Turkey, from $32.6 \%$ in 1990 to around 20\% during the early 2000s, with a slight improvement after 2015. According to the most recent data, the employment rate of women was $32.9 \%$ in 2018 , compared to $70.9 \%$ for men, resulting in one of the highest gender employment gaps in the world (Table 1). This trend is in marked contrast to the increasing employment rates observed amongst members of the European Union (EU) and the Organization for Economic Co-operation and Development (OECD), or in

\footnotetext{
3 These concepts which CAMSIS is suggested to capture were used interchangeably throughout the paper as a means of gauging social inequality. The CAMSIS project has been analyzing social interactions between occupations across countries and providing scale values that indicate an occupation's relative positioning in the social stratification. Other measures could also be used to rank occupations on the vertical axis. A common alternative, the international socioeconomic index (ISEI) (Ganzeboom et al. 1992), which is broadly viewed as a proxy for occupational prestige, was not used, as it is still more of an economic measure in which occupations are conceptualized as a means of transforming education into earnings. However, later in the paper, we also referred to vertical segregation measures based on ISEI
}

countries with similar levels of economic development to Turkey. ${ }^{4}$

Turkey experienced a rather rapid social and structural transformation after the foundation of the Republic in 1923. Although the shift from agriculture to industry was slow during the early phase of economic modernization movements, the increase in the share of industrial production accelerated after the 1950s; this has been accompanied by high rates of urbanization. The extent of the rural-urban migration was siesmic in that the share of the urban population rose from $25.0 \%$ in 1955 to $76.3 \%$ in 2010 (TurkStat, Population Censuses 2010). Since the early 1980s, Turkey has become more integrated with the rest of the world due to export-led growth strategies and increased market liberalization, the deregulation of finance, and the privatization of state enterprises. From the 1980s, although interrupted by the 1994 and 2001 major currency crises and, to an extent, by the 2008 global crisis, robust economic growth figures have also been observed.

However, neither of these developments brought about improvements in women's employment. The increase in non-agricultural-sector employment was lower than the share of the population entering the labor force in urban areas through mass migration. Women who used to work as unpaid family workers in small-scale family farms were excluded from the urban labor market due to their lower educational levels and limited labor market experience, as well as due to strong cultural values that regarded women as homemakers (Dayığlu and Kırdar 2010). Although exportled strategies adopted since the 1980s have resulted in the expansion of the labor-intensive sectors which offered job opportunities to women (mainly in textiles and garments),

\footnotetext{
4 The rates are also lower than those of around $40-50 \%$ in Chile, Korea, and Mexico, which, like Turkey, are classified as developing countries in the International Monetary Fund's (IMF) World Economic Outlook Report (IMF 2014) (the figures are available at https ://stats.oecd.org/\#).
} 
Fig. 1 The share of service industry in total employment and in female employment, Turkey-EU28 comparison. Source International Labor Organization Web database, ILOSTAT, Available at https:// www.ilo.org/shinyapps/

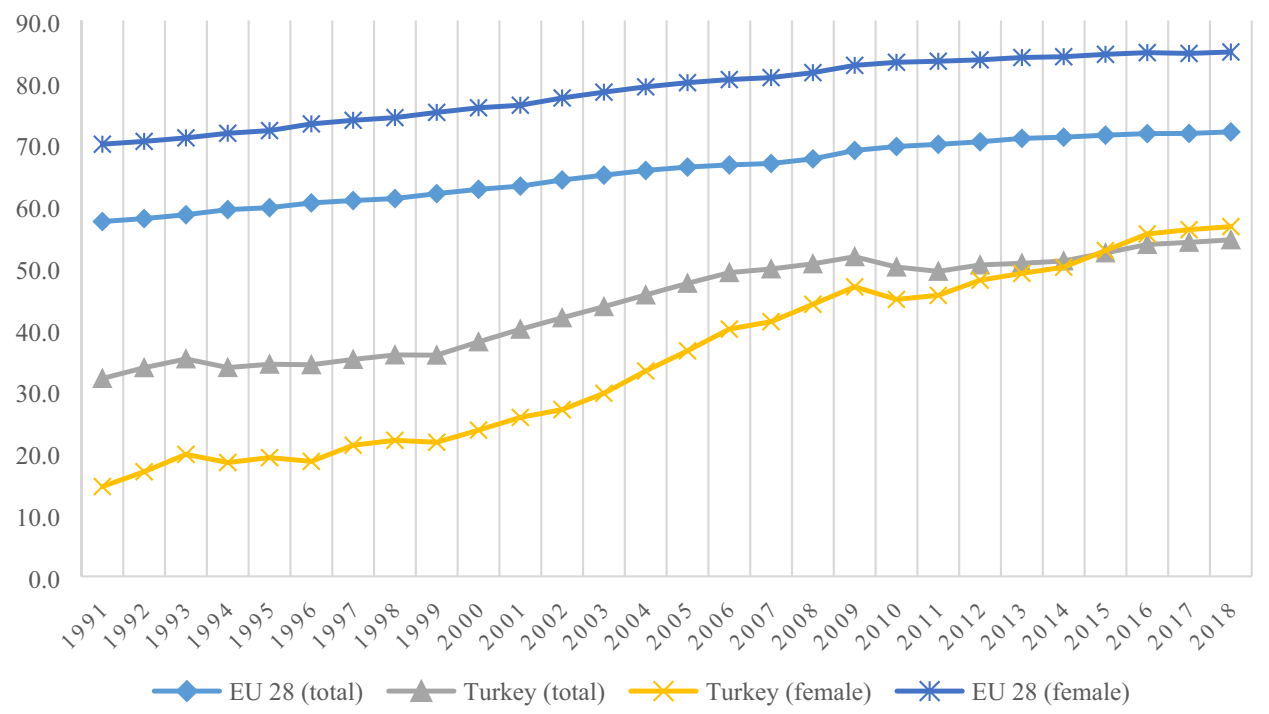

they were concentrated in unfavorable jobs in the informal sector, with low pay or no social security (Dedeoğlu 2010). ${ }^{5}$ Nevertheless, the high-interest-rate policies of the early 2000s shifted the competitiveness of exports towards the motor vehicle and machinery sectors, where men dominated employment (İlkkaracan 2012). Similarly, the privatization of state-owned enterprises operated to the disadvantage of women, as the remaining public enterprises were mainly in energy and mining (Buğra and Yakut-Cakar 2010).

There has been a steady rise in service sector employment since the early 2000s (Fig. 1). In parallel, the share of the service sector across female employment also rose steadily. However, the share of services and women's employment within the sector was still considerably lower than the EU averages. Additionally, unlike the general trend in developed countries, women's representation remained low in certain sub-sectors of services, such as business services or social services, which could potentially offer more prestigious occupations for them (Buğra and Yakut-Cakar 2010). ${ }^{6}$ This cannot be attributed solely to women's lower educational qualifications, as whilst the gap in the proportion of men and women with higher education has decreased in Turkey, this was not accompanied by a closing of the gap between their labor force participation rates or their position in the occupational hierarchy (Günlük-Senesen and Özar 2001; İlkkaracan 2012).

\footnotetext{
5 The share of informal work was quite high amongst women in Turkey, at $58.49 \%$ in 2010 , whereas this figure was $37.19 \%$ for men. The most recent figures from 2018 indicate that the share of informal work fell to $42.14 \%$ for women and $29.43 \%$ for men (TurkStat, Labor Force Surveys 2010-2018).

${ }^{6}$ As will be seen later, the descriptive statistics presented in this paper documented similar facts.
}

These all pointed to the role of society-specific elements, especially the strength of traditional or conservative social norms and cultural values, in reinforcing the gendered division of labor at home and in the labor market in Turkey, as well as in limiting the potential for structural transformation that would help women progress towards decent occupations. Time-use literature has documented the prevalence of the traditional family structure in which men are breadwinners and women are homemakers or second earners. The incidence of dual-earner couples has been historically low in Turkey, and women have continued to undertake a disproportionate share of housework and caring activities even when employed, pointing to the double burden of paid and unpaid work (Kaya Bahçe and Memiş 2013; Kongar and Memiş 2017).

Traditionalism in gender roles and the male breadwinner/female homemaker norm has prevailed in the legal and institutional framework in Turkey, particularly in work and family reconciliation policies. Given the lack of affordable childcare services and a conservative family-oriented care regime that relied mainly on women's inactivity, women have preferred to stay at home, given the fact that the wages they were likely to receive were usually lower than their reservation wages, which were increased by high childcare costs (Taymaz 2010). Moreover, rather than enhancing accessible public institutional care facilities, current measures, such as cash transfers to poor families with children along with cash benefits provided for the care of the elderly and disabled at home, served to increase home care provision, which strengthened the notion of confining women to the domestic sphere (Bozçağa 2013). ${ }^{7}$

\footnotetext{
${ }^{7}$ Regulations were passed to promote the presence of childcare facilities at work. Workplaces with more than 100 female workers are required to set up nursing rooms or facilitate private nurseries, while those with 150 or more female workers are supposed to provide day
} 
In parallel, recent policies to support female employment were oriented towards enhancing women's contribution to family income in cooperation with traditional and conservative values. Tax exemptions for the income that women generated from the sale of products they produced domestically, as well as the use of Grameen Bank type microcredits (introduced in the early 2000s), were said to encourage female entrepreneurship through a conservative viewpoint, as they enabled women to contribute to the family budget without working outside their homes (Buğra and Yakut-Cakar 2010).

Overall, these measures are unlikely to challenge the dominant norms and gender stereotypes, nor will they change women's segregation into occupations that are "merely an expansion of household activities" (Anker 1998, p. 139). Nevertheless, the literature on the overall occupational structure in Turkey is quite dated and utilizes unidimensional measures, ignoring the vertical and horizontal dimensions. For example, using population census data from 2000, Rich and Palaz (2008) showed that $21.7 \%$ of employed people in Turkey would have to change their jobs to achieve an even distribution of men and women across occupations. On the other hand, more recent evidence draws attention to the gender dynamics behind women's concentration in specific sectors of employment. For example, the large proportion of women in the higher education sector in Turkey has been attributed to gender stereotypes and the sex-typing of teaching-oriented academic jobs as safe and suitable career choices for women. In parallel, women have been under-represented in higher-ranked positions in the academic hierarchy (Özbilgin and Healy 2004; Sağlamer et al. 2018). Career breaks due to pregnancy and motherhood, family obligations, and the associated difficulties in managing work-life balance were the main obstacles preventing women's career advancement in the sector (Sağlamer et al. 2018). Such impediments and women's slim representation in managerial positions were also noted in the banking sector (Günlük-Senesen and Özar 2001; Özbilgin and Woodward 2004).

The key objective of this paper was to provide a thorough investigation of occupational gender segregation in Turkey, not just in certain sectors or sub-sections of occupations but across the overall occupational structure. To that end, it decomposed the overall occupational gender segregation into vertical and horizontal components. This allowed us to investigate the extent to which the differentiation in men's and women's occupations was an indication of the limited

\section{Footnote 7 (continued)}

care. As Dayığlu and Kırdar (2010) stated, the dependence of these provisions on only the number of female workers, instead of on the number of workers in total, caused a disparity in the cost of employing women and men. occupational choices available to them (captured by the horizontal component) whilst pointing to the role of unsatisfactory social and structural changes, the persistence of common stereotypes, and a gendered division of labor. Analysis of the vertical component, on the other hand, enabled us to shed light on the further inequalities these could produce in terms of pay and social status. The sub-sections of the paper explored whether occupational gender segregation and its dimensions varied in relation to main demographics (such as age, education, and marital status) and industries-in particular, services and public sector employment, which were shown to expand job opportunities for women. It thereby contributed to the ongoing discussion of the relationship between changes in the industrial structure and women's employment by investigating the extent to which these changes helped tackle the issue of occupational gender segregation and the inequality associated with it or fostered the institutionalization of gender across the occupational structure.

\section{Methods}

Following Blackburn et al.'s approach, segregation was conceptualized as having two dimensions or components-a vertical one capturing inequality and an orthogonal horizontal one capturing the difference in occupational distributions. Together, these two dimensions formed the overall occupational segregation. This required the measurement of the overall segregation and its vertical and horizontal components in comparable ways, using the same metric. Therefore, the Gini coefficient was employed to measure the overall segregation, whereas Somers' D was used for the vertical component.

The Gini coefficient and Somers' D are compatible with each other in the sense that both use the same statistic for the same occupational groupings; however, the ordering of the occupations is based on different tools. While the Gini coefficient (referred to as a limiting case of Somers' D by Blackburn et al. 2001) ranks occupations from the most to least female-dominated or vice versa, Somers' D ranks occupations by the criteria of occupational inequality. Here, average pay levels and the CAMSIS scores of the occupations were used. In terms of pay, to acknowledge any variations, the averages of both monthly and hourly pay levels of all workers in an occupation were calculated.

Accordingly, the Gini coefficient can be computed as follows:

$$
G=\sum_{i=2}^{n}\left[\sum_{1}^{i-1} W_{t} / W \sum_{1}^{i} M_{t} / M-\sum_{1}^{i} W_{t} / W \sum_{1}^{i-1} M_{t} / M\right]
$$


where $i$ denotes the $i$ th occupation, $n$ is the total number of occupations, and $t$ indicates an occupation included in the cumulative total. $W_{t}$ and $M_{t}$ denote the number of women and men in occupation $t, W_{i}$ and $M_{i}$ denote the number of women and men in occupation $i$, and $W$ and $M$ denote the number of women and men in the labor force. The Gini coefficient can be explained by its relationship with the Lorenz curve (segregation curve), which represents the cumulative proportion of women in the lor force against men in the labor force after the occupations are ordered according to the ratio of the number of women and men (i.e., $\left.W_{i} / M_{i} \geq W_{i+1} / M_{i+1}\right)$. When there is no segregation, the Lorenz curve corresponds to the main diagonal (a straight line) and the Gini coefficient is equal to 0 . When there is segregatn, Gini coefficient measures the area between the main diagonal and $t$ Lorenz $\mathrm{c}$.

Blackburn et al. (2001) documented that that Gini coefficient can be expressed in terms of Somers' D as follows:

$$
\begin{aligned}
G= & {[1 / W M] \sum_{i=2}^{n}\left[\sum_{1}^{i-1} W_{t}\left(\sum_{1}^{i-1}\left(M_{t}+M_{i}\right)\right)\right.} \\
& \left.-\left(\sum_{1}^{i-1}\left(W_{t}+W_{i}\right)\right) \sum_{1}^{i-1} M_{t}\right]
\end{aligned}
$$

$G=[1 / W M] \sum_{i=2}^{n}\left(M_{t} \sum_{1}^{i-1} W_{t}-W_{i} \sum_{1}^{i-1} M_{t}\right)$

The formula for the Gini coefficient can be interpreted as ordering the pairs of men and women by the gender composition (i.e., femaleness/maleness) of the occupations they hold (Blackburn et al. 2001, p. 534). If $C$ denotes concordant pairs (that is, the woman is employed in an occupation with a greater share of women and the man is employed in an occupation with a greater proportion of men) and if $D$ stands for the discordant pairs (meaning that the woman is employed in a male-dominated occupation a the man is employed in a female-dominated occupation), the Gini coefficient becomes:

$G=(C-D) / W M$

where $C=\sum_{i=2}^{n}\left(M_{t} \sum_{1}^{i-1} W_{t}\right)$. and $D=\sum_{i=2}^{n}\left(W_{i} \sum_{1}^{i-1} M_{t}\right)$.

which is actually Somers' D, a measure of associationh an independent variable that can take two values (men and wom, in this paper). In other words, when occupations are ordered from the most to least female-dominated or vice versa, the value for Somers' D is maximized and becomes the Gini coefficient. ${ }^{8}$ The Gini coefficient is the maximum value of $\mathrm{D}$ for a $2 x n$ table including men and women and $n$ occupations ranked from the most female to the most male. When occupations are ranked by the criterion of occupational inequality (in our case, by the mean hourly pay levels and stratification scale scores), Somers' D measures the vertical dimension of segregation. Therefore, the Gini coefficient for the overall segregation and Somers' D for its vertical dimension are strictly comparable measures in the sense that both are measured by Somers' D.

As with the values of the Gini indices measuring overall oupational gender segregation which vary between 0 to $1(0$ representing aotal integration by gender and 1 representing a total segregation by gender), vertical segregation indices also take the values between 0 and 1 but in absolute terms. A positive vertical segregation value indicates woman's disadvantageous position compared to man across the occupations. However, the vertical component can also be negative, indicating an advantage for women. The greater the absolute index value, the larger the extent of the advantage or disadvantage.

Finally, the horizontal component of segregation is conceptualized as being orthogonal to the vertical component and, thereby, calculated using Pythagoras' theorem as follows:

\section{Horizontalsegregation}

$$
=\sqrt{\left[(\text { overallsegregation })^{2}-(\text { verticalsegregation })^{2}\right]}
$$

Horizontal segregation represents the residual association between gender and occupational structure once the gender differences in terms of a vertical criterion (vertical segregation) are identified. Because horizontal segregation is defined as the difference without inequality, it can be only positive (Blackburn et al. 2001).

\section{Data and Descriptive Statistics}

The data for analyzing occupational gender segregation came from the 2010 Household Labor Force Survey (HLFS) undertaken by TurkStat. The sample was restricted to individuals aged 15 to 65 who were currently employed - a total of 153,920 currently working individuals, of whom 45,029 were women and 108,891 were men. However, given our interest in investigating the degree to which women were employed in lower-paid occupations, the data were further restricted to regular/casual employees whose pay data were

\footnotetext{
${ }_{8}$ See Blackburn et al. (2001) and Blackburn (2009) for more detailed information about formulation and conceptualization.
} 
Table 2 Employment distribution by occupational groups, average pay levels and CAMSIS Scores across the occupations

\begin{tabular}{|c|c|c|c|c|c|}
\hline & Total & Women's share & $\begin{array}{l}\text { Women's aver- } \\
\text { age pay levels }\end{array}$ & $\begin{array}{l}\text { Men's } \\
\text { average pay } \\
\text { levels }^{\mathrm{a}}\end{array}$ & CAMSIS score \\
\hline 11-Legislators and senior officials & 0.62 & 7.02 & 1892.85 & 1183.38 & 52.69 \\
\hline 12-Corporate managers & 2.83 & 21.33 & 1806.72 & 1868.67 & 67.2 \\
\hline 13-Managers of small enterprises & 0.86 & 9.63 & 1278.77 & 1173.97 & 54.37 \\
\hline 21-Physical, mathematical and engineering science professionals & 1.36 & 26.02 & 1688.03 & 1992.56 & 70.09 \\
\hline 22-Life science and health professionals & 1.06 & 40.32 & 1923.89 & 2135.02 & 71.44 \\
\hline 23-Teaching professionals & 5.67 & 52.61 & 1478.55 & 1681.69 & 72.56 \\
\hline 24-Other professionals & 2.73 & 24.81 & 1431.40 & 1792.06 & 67.39 \\
\hline 31-Physical and engineering science associate professionals & 2.91 & 18.57 & 880.88 & 1283.89 & 60.84 \\
\hline 32-Life science and health associate professionals & 1.77 & 71.29 & 1436.04 & 1253.15 & 66.79 \\
\hline 33-Teaching associate professionals & 0.22 & 76.43 & 690.81 & 795.24 & 52.73 \\
\hline 34-Other associate professionals & 4.27 & 28.02 & 1197.91 & 1285.73 & 60.39 \\
\hline 41-Office clerks & 8.33 & 41.91 & 933.22 & 1115.55 & 57.41 \\
\hline 42-Customer services clerks & 2.92 & 46.03 & 973.58 & 1082.31 & 58.4 \\
\hline 51-Personal and protective services workers & 10.36 & 18.93 & 654.34 & 989.99 & 53.23 \\
\hline 52-Models, salespersons and demonstrators & 6.15 & 23.00 & 624.61 & 729.10 & 51.76 \\
\hline 61-Market-oriented Skilled agricultural and fishery workers & 0.80 & 9.31 & 428.23 & 675.85 & 16.62 \\
\hline 62-Subsistence agricultural and fishery workers & 0.00 & 0.00 & & 700.00 & 14.44 \\
\hline 71-Extraction and building trades workers & 4.55 & 0.56 & 589.02 & 840.85 & 46.06 \\
\hline 72-Metal, machinery and related trades workers & 5.92 & 1.85 & 696.42 & 850.57 & 48.7 \\
\hline 73-Precision, handicraft, craft printing and related trades workers & 0.90 & 13.45 & 567.07 & 798.03 & 54.33 \\
\hline 74-Other craft and related trades workers & 5.20 & 19.48 & 558.02 & 746.71 & 48.47 \\
\hline 81-Stationary plant and related operators & 1.15 & 1.96 & 602.20 & 880.27 & 48.41 \\
\hline 82-Machine operators and assemblers & 7.47 & 21.45 & 650.61 & 791.00 & 49.28 \\
\hline 83-Drivers and mobile plant operators & 6.36 & 0.16 & 685.32 & 939.42 & 48.03 \\
\hline 91-Sales and services elementary occupations & 8.28 & 23.09 & 575.43 & 728.39 & 45.76 \\
\hline 92-Agricultural, fishery and related laborers & 1.75 & 40.11 & 410.92 & 513.20 & 24.41 \\
\hline 93-Laborers in mining, construction, manufacturing and transport & 5.60 & 17.40 & 583.41 & 712.75 & 43.73 \\
\hline Total & 100.00 & & & & \\
\hline Number of observations & 84,444 & 19,522 & & & \\
\hline
\end{tabular}

Sample weights are used

${ }^{a}$ These are the average monthly pay levels in Turkish Liras

available, consisting of 84,444 individuals (19,522 women and 64,922 men). ${ }^{9}$

The 2010 HLFS provided data on occupations coded at the two-digit International Standard Classification of Occupations 1988 (ISCO-88), covering 27 occupational categories. Although such less-detailed occupational data were likely to underestimate the extent of occupational segregation, Blackburn (2009) considered 20 occupational categories as an "appropriate minimum" (p. 14) and Anker (1998)

\footnotetext{
9 Observations with extreme (and implausibly) high and low values (e.g., much less than minimum wages) for pay data were also excluded; however, these exclusions resulted in very small changes in the sample size.
}

argued that disaggregating occupational groupings from the two-digit to three-digit level did not result in a substantial difference in the segregation measures. More pragmatically, the analysis for Turkey required working on two-digit ISCO88 data, as more detailed occupational groupings were not available. Previous HLFS surveys or those released after 2010 did not present sufficient occupational information, as they provided one-digit occupational data with only nine occupational categories.

Table 2 shows the employment distribution of women and men, the average pay levels for women and men across the occupations, and the associated CAMSIS scores. Not surprisingly, the female share was greatest amongst "Life science and health associate professionals" and "Teaching associate professionals", which typically involve "female" 
Table 3 Overall segregation and the associated vertical and horizontal dimensions

\begin{tabular}{llll}
\hline & $\begin{array}{l}\text { Vertical segregation } \\
\text { measured by mean } \\
\text { hourly pay }\end{array}$ & $\begin{array}{l}\text { Vertical segregation } \\
\text { measured by mean } \\
\text { monthly pay }\end{array}$ & $\begin{array}{l}\text { Vertical segregation } \\
\text { measured by CAMSIS }\end{array}$ \\
\hline Overall & 0.480 & 0.480 & 0.480 \\
Horizontal & 0.436 & 0.446 & 0.379 \\
Vertical & 0.199 & 0.176 & 0.294 \\
Number of occupations & & 27 & \\
Number of observations & & 84,444 & \\
\hline
\end{tabular}

A positive (negative) vertical segregation value indicates woman's disadvantageous (advantageous) position compared to man across the occupations. The greater the absolute index value, the larger the extent of the advantage or disadvantage jobs such as nurses and primary school teachers. Their share was also high amongst office and customer service clerks. On the contrary, their representation was low in higherranked occupations that involve decision-making, such as "Legislators, senior officials and managers" or "Corporate Managers". With the exception of "Legislators, senior officials and managers", the average pay levels for men were greater than those for women across occupations.

Similar to trends observed elsewhere, the social stratification structure captured by CAMSIS indicated that professionals constituted the top positions across the social hierarchy in Turkey. They were followed by corporate managers (see https://www.camsis.stir.ac.uk/versions.html for CAMSIS country profiles). As might be expected, manual occupations such as laborers in mining, construction, manufacturing, and transport; agricultural, fishery and related laborers; subsistence agricultural and fishery workers; extraction and building trades workers; and unskilled sales and services elementary occupations fell into the lowest positions in the stratification order. The middle of the occupational order consisted of clerical jobs (office clerks and customer service clerks) followed by associate professionals and managers of small enterprises.

Other than in the categories of teaching professionals and associate professionals in life science and health, women's shares were lower than those of men in occupations with higher CAMSIS scores. However, women were also outnumbered by men in occupations that rank lower in social status. The next section explores this further by estimating whether it was men or women who had a greater tendency to hold occupations with a lower social status. ${ }^{10}$

\footnotetext{
${ }_{10}$ On a final note, because the sample excluded unemployed women, it could be argued that one of the reasons for women's over-representation in low-paid, low-status occupations was their higher unemployment rates across the highest end of the wage and social hierarchy distribution. In this sense, although it does not entirely eliminate this possibility, the official statistics indicating that female unemployment rates were lower amongst women with higher education were reassuring. For example, the (non-agricultural) unemployment rate amongst women with higher education was $16.0 \%$ in 2010 , while this figure
}

\section{Empirical Results on the Extent of (Overall) Occupational Gender Segregation and Its Dimensions in Turkey}

The results for overall occupational gender segregation and the vertical and horizontal dimensions are presented in Table 3. The overall gender segregation was 0.480 . Although it was difficult to achieve a direct comparison with other countries, this figure was relatively low and was, perhaps, a reflection of the very low representation of women in the labor market, in line with studies finding a positive association between female employment rates and occupational segregation figures (e.g., relatively lower occupational gender segregation figures for Italy and Greece which are characterized by lower employment rates for women) (Emerek et al. 2003; Jarman et al. 2012; Mandel and Semyonov 2006). ${ }^{11}$

When the vertical dimension was measured by pay, it was associated with a positive sign ( 0.199 for hourly pay, 0.176 for monthly pay), indicating the expected advantaged position of men in terms of pay. In other words, women had a greater tendency to be employed in lower-paid jobs. However, the horizontal dimension was considerably larger than the vertical dimension. Therefore, overall segregation owed more to the differences in the patterns of male and female employment across occupations than to the inequality (measured by pay) prevalent in this pattern. ${ }^{12}$

The vertical dimension measured by CAMSIS was 0.294 , which was substantially larger than the values obtained for

\section{Footnote 10 (continued)}

was $26.6 \%$ for high school graduates and $34.4 \%$ for those with less than a primary school diploma (TurkStat, Labor Force Surveys 2010).

${ }^{11}$ For example, Jarman et al. (2012) reported the Gini coefficient for overall occupational segregation as 0.767 for Finland, 0.747 for Denmark, 0.636 for Romania, 0.647 for Greece, and 0.667 for Italy, based on the 2000-2006 European Social Survey. However, the number of occupations used was much greater in Jarman et al.'s study as compared to the 27 occupational groups that this paper uses.

12 Vertical segregation measured by ISEI was 0.172 , which was very close to the value observed for pay. 
Fig. 2 Overall occupational gender segregation (OS) and the vertical dimension (VS) by education. Note: A positive (negative) vertical segregation value indicates woman's disadvantageous (advantageous) position compared to man across the occupations. The greater the absolute index value, the larger the extent of the advantage or disadvantage

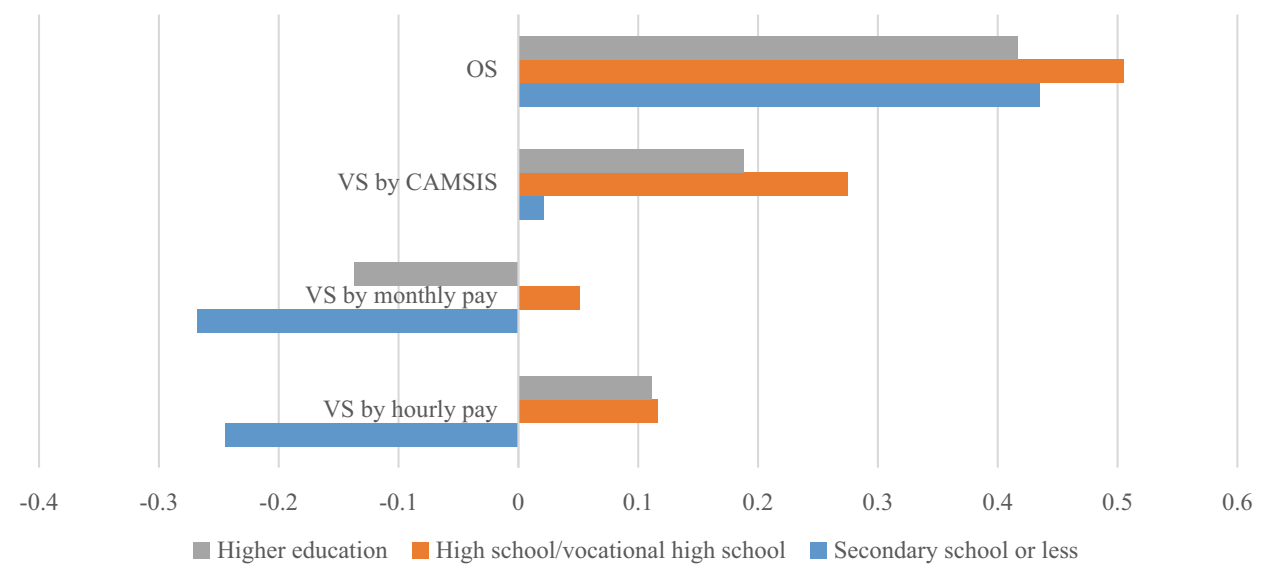

pay. That is to say, women were at an even more disadvantaged position in terms of social stratification; they had a greater tendency than men to be employed in occupations that ranked lower in the overall social hierarchy. Once again, the horizontal dimension was larger than the vertical dimension. Therefore, the overall segregation was due to the fact that men and women were employed in horizontally different occupations; however, it was accompanied by a considerably greater level of inequality when the vertical dimension was measured using CAMSIS.

It can, therefore, be concluded that women were always in a disadvantaged position with respect to men. It was particularly striking that women had a substantially greater probability of being employed in lower-ranked occupations across the social stratification structure. Therefore, in addition to the economic inequalities that women faced, they were exposed to social inequalities in the occupational structure. A larger horizontal dimension of overall segregation was found regardless of whether the vertical dimension was measured by pay or by CAMSIS, though the extent was smaller in the latter. However, it is important to stress that although the horizontal dimension does not bring about inequality in the form of pay or social hierarchy, it implies a distributional inequality in terms of a more limited set of occupational choices for both women and men. This might be particularly pronounced in Turkey given that the horizontal segregation figures are more sensitive to the traditional gender norms and cultural values (Charles 2003) which remain strongly influential in the country.

Whilst this analysis was useful in terms of providing insight into the extent of occupational gender segregation, gender segregation is not static, nor does it always imply a female disadvantage (Burchell et al. 2014). The factors leading to occupational gender segregation are dynamic; the structure of the economies, attitudes towards women and work, and women's investment in skills are all changing. In the absence of longitudinal data, sub-group analyses across a cross-section can be helpful in understanding the underlying dynamics and speculating on the strength of the factors contributing to a segregated workforce. To that end, we first calculated the occupational gender segregation indices by educational groups, age, and marital status and then investigated the variations in relation to the industrial composition and public/private sector employment.

\section{Sub-group Analyses of Occupational Gender Segregation}

\section{Differentials According to the Main Demographics}

As previously noted, women's educational attainments have improved significantly in Turkey. Our data showed that employed women actually held better educational qualifications than did men across the majority of occupations, particularly amongst legislators, senior officials and managers, and professionals (Table 5 in the Appendix). Accordingly, we observed relatively lower overall occupational gender segregation figures amongst women and men with higher education (Fig. 2). ${ }^{13}$ Although this may suggest that some highly educated women have made their way into genderatypical occupations in Turkey (similar to the general trend observed elsewhere), the vertical dimension suggested that their return, in terms of both hourly pay and social status, remained lower than that for men. That is to say, women's entry into such occupations was not enough to counteract the gender-unequal outcomes.

Figure 3 shows the segregation figures by marital status. As might be expected, overall gender segregation was

\footnotetext{
13 As our core interest in this section was to investigate the extent of the overall differentiation of men and women across the occupations and the associated inequality measured by pay and CAMSIS, the figures for the residual horizontal dimension were not always presented here, for the sake of brevity (as horizontal segregation values change according to the vertical criteria used and the sub-group analyzed). However, the author can provide these upon request.
} 
Fig. 3 Overall occupational gender segregation (OS) and the vertical dimension (VS) by marital status. Note: A positive (negative) vertical segregation value indicates woman's disadvantageous (advantageous) position compared to man across the occupations. The greater the absolute index value, the larger the extent of the advantage or disadvantage

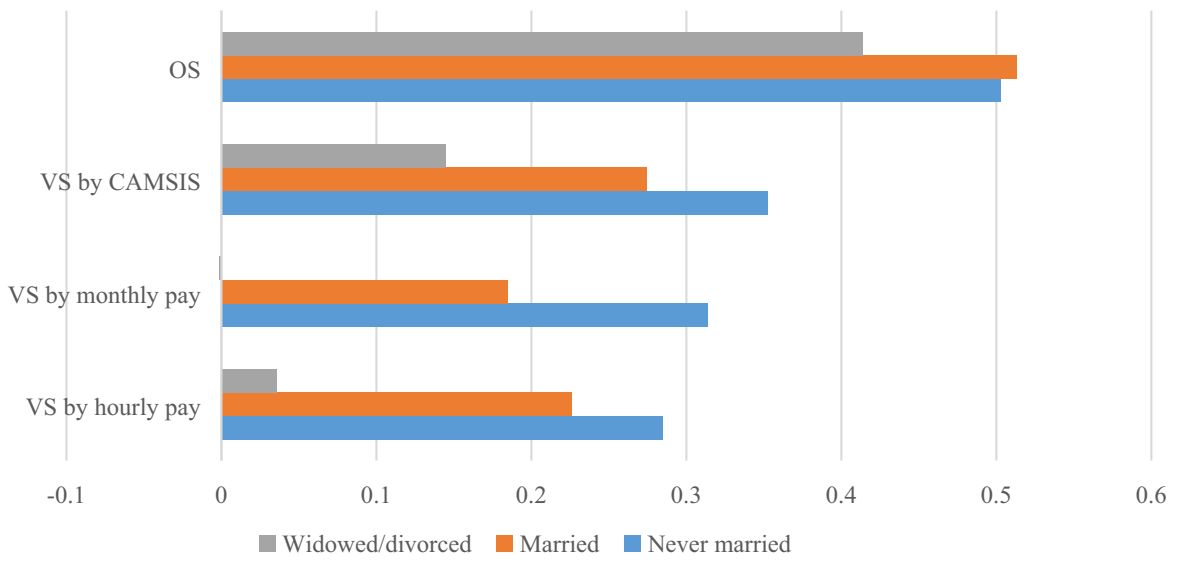

highest amongst married individuals, possibly indicating women's likely tendency to be employed in certain occupations which offer greater flexibility and work-family balance. The share of married women was larger primarily in typically "female" and more family-friendly occupations such as "Life science and health (associate) professionals", "Teaching professionals", and "Sales and services elementary occupations" (Table 5 in Appendix). However, given that the difference in the magnitude of overall segregation between the married and never-married samples was too small (top panel of Fig. 3), there were concerns that this difference would disappear once the age composition was taken into account. To test this, one could compare the segregation indices across the subgroups representing five years before and five years after the average age of first marriage. It was not possible to infer this information from the data but, according to the official figures, the average age at first marriage was 23.7 for women and 27.0 for men, while the mean age for giving birth was 27.7 in 2010 (TurkStat. Marriage Statistics 2010). Acknowledging that being married did not necessarily translate into having a child, occupational gender segregation figures were calculated separately for married and single individuals across different age groups. Accordingly, it was assumed that the age group "20-24" would reflect the time before having children, the age group "25-29" would reflect the age of having a child, and the age group "30-34" would indicate the period after having a child. Figures 4 and 5 present the occupational segregation measures derived from these attempts.

Overall occupational gender segregation peaked at age 25-29 for married individuals and its extent was larger than that observed for never-married individuals. Additionally, this owed almost equally to the pure differentiation in the occupations that men and women hold and the accompanied vertical inequality. Actually, the vertical dimension was larger than the horizontal dimension when the vertical segregation was measured by CAMSIS. Overall occupational gender segregation declined after age 25-29, with a lower vertical dimension and a horizontal dimension which remained comparable across age groups. This potentially illustrated the marriage/children effect whereby women withdrew from the labor market or moved to certain occupations upon having a child. On the other hand, for singles, occupational gender segregation beyond the age group 25-29 started owing more to inequality in terms of pay and social status, whilst the extent of the horizontal dimension decreased.

To complete the overall picture, occupational gender segregation and its dimensions were also calculated across the age groups for the overall sample. Occupational gender segregation was greatest at the age of 25-29, reinstating the arguments above (Fig. 6). Across the age groups 15-24 and 25-29, overall segregation was accompanied by a noteworthy vertical dimension operating to the detriment of women, especially in terms of social stratification. Beyond the age group 25-29, overall occupational segregation diminished, as did the extent of inequality associated with it. This decline in overall segregation might be explained by the fact that there were simply fewer women working. ${ }^{14}$ In terms of the decline in the vertical dimension, on the other hand, it was possible that the women experiencing the most disadvantages were the ones in more traditional contexts and, therefore, stopped working when they got married.

\section{Differentials According to the Structure of the Labor Market}

As noted earlier, research pointed to the noteworthy role of structural transformation in women's employment outcomes and occupational status. In addition to bringing more women to the labor market, the expansion in the service sector was

\footnotetext{
${ }^{14}$ It is important to note that the Somers' D statistic was not statistically significant for the age groups beyond $45-49$, potentially because of the small sample size.
} 
Fig. 4 Overall occupational gender segregation (OS) its horizontal and vertical dimensions amongst married and single individuals by age groups (VS measured by pay ${ }^{1}$ ). Note: A positive (negative) vertical segregation value indicates woman's disadvantageous (advantageous) position compared to man across the occupations. The greater the absolute index value, the larger the extent of the advantage or disadvantage. ${ }^{1}$ Pay is measured as hourly pay. Results were similar for the monthly pay and could be provided upon request
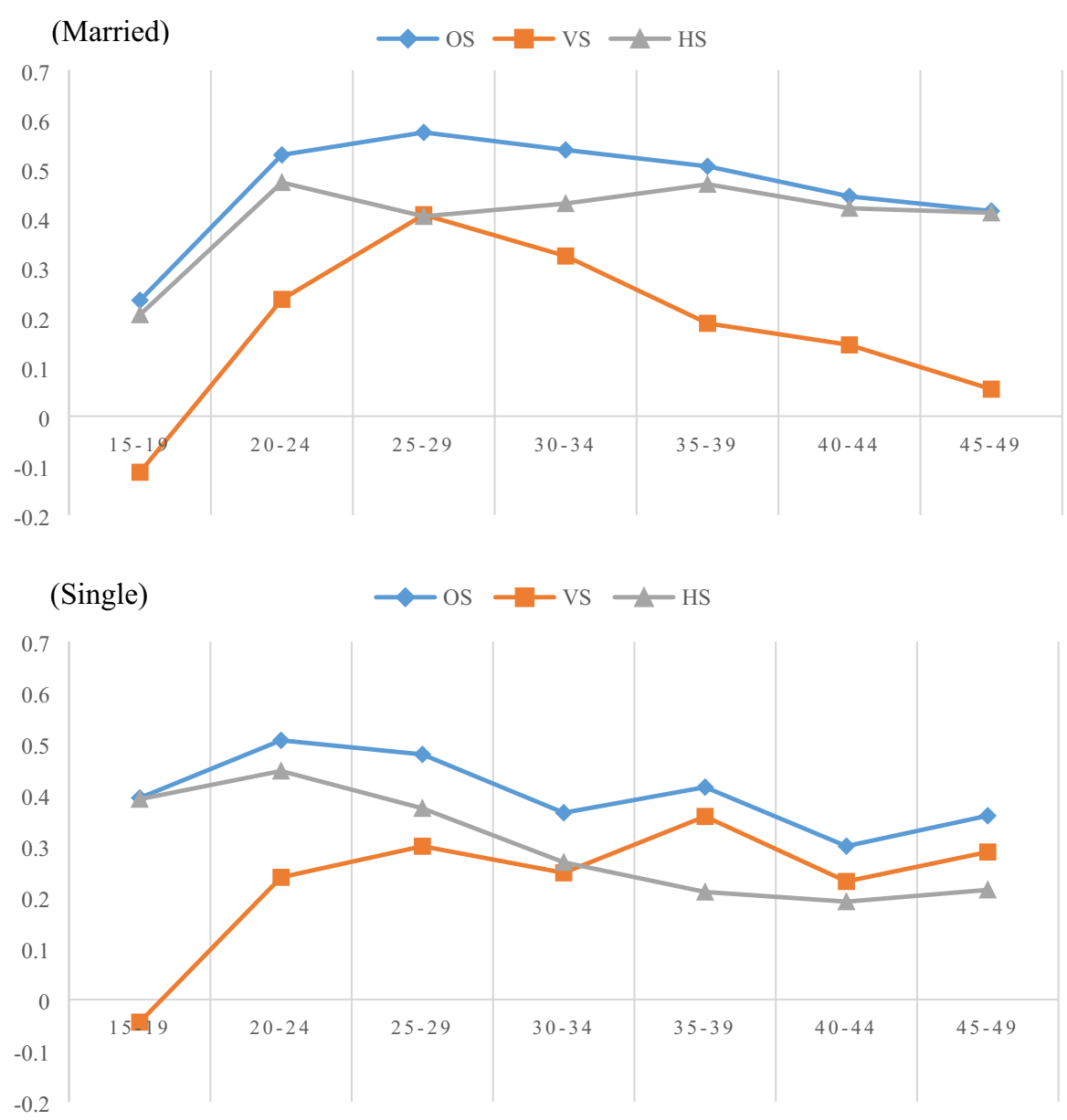

shown to have reduced the gender wage gap and promoted women's representation in non-manual work (potentially amongst professionals) with better occupational standing (Blackburn and Jarman 2006; Burchell et al. 2014; Goldin 2006; Jarman et al. 2012; Ngai and Petrongolo 2017). Therefore, though it was associated with an increased differentiation in employment patterns between men and women (Burchell 1996; Charles 2003; Emerek et al. 2003), research suggested that, at least in industrialized countries, the rise in the service sector led to improvements in the vertical component of occupational segregation. This reflected high overall segregation which was countered by a relatively lower vertical dimension, as observed in the Scandinavian countries. However, it was also argued that a large service sector implies the incorporation of traditionally female tasks, such as caring, food services, weaving, or making clothes, into the formal economy (Charles 1992; Mandel and Semyonov 2006). The latter argument can be particularly strong in countries like Turkey, given that women's integration into the service sector with potentially favorable occupational outcomes was limited..$^{15}$

To be able to comment upon these, occupational gender segregation was investigated across different industries, with a particular focus on the contribution of the service sector. Furthermore, segregation figures were calculated separately for the public and private sectors, as research addressed the opposing effects of public sector employment on women's access to gender-atypical occupations.

Table 4 presents the overall occupational segregation and associated vertical dimension by industries, along with their share amongst female employment. As might be expected, women's representation was extremely low amongst the "Construction", "Mining and quarrying" and "Electricity, gas and water supply" industries, which

\footnotetext{
15 The extent of part-time employment is also an important driver of occupational gender segregation. However, part-time work is not a fundamental source of employment in Turkey and its incidence is quite low among both men and women. According to the 2010 HLFS, the part-time employment share was $6.60 \%$ for women and $2.21 \%$ for men.
} 
Fig. 5 Overall occupational gender segregation (OS) its horizontal and vertical dimensions amongst married and single individuals by age groups (VS measured by CAMSIS). Note: A positive (negative) vertical segregation value indicates woman's disadvantageous (advantageous) position compared to man across the occupations. The greater the absolute index value, the larger the extent of the advantage or disadvantage
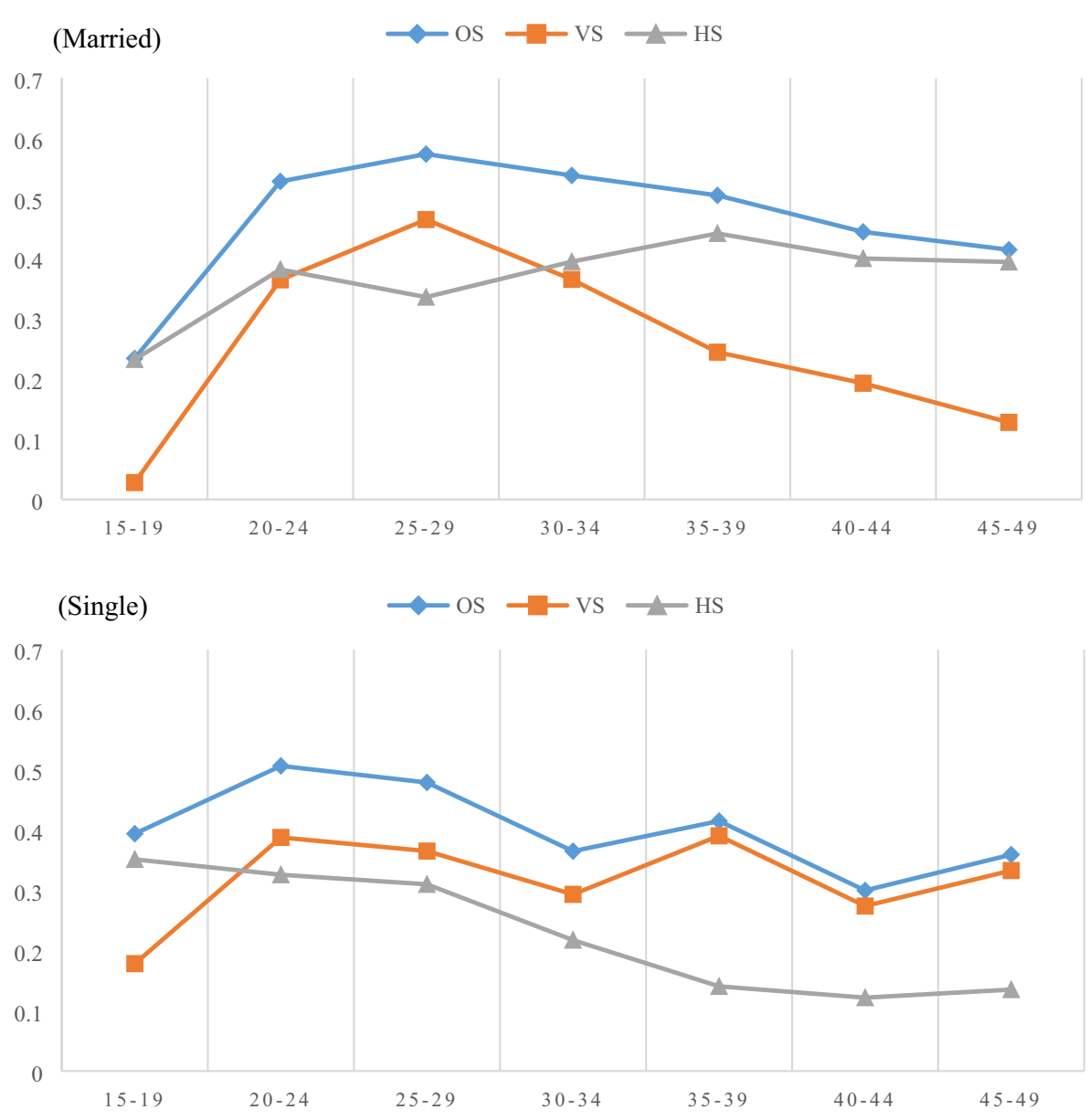

Fig. 6 Overall occupational gender segregation (OS) and the vertical dimension (VS) by age. Note: A positive (negative) vertical segregation value indicates woman's disadvantageous (advantageous) position compared to man across the occupations. The greater the absolute index value, the larger the extent of the advantage or disadvantage

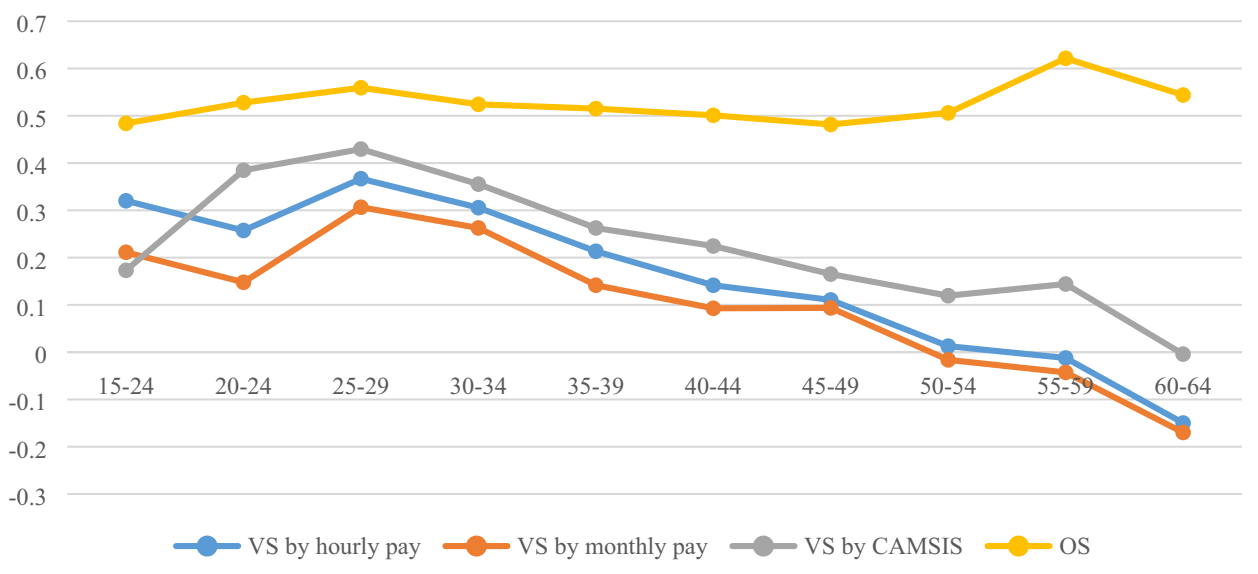

consist of typically male jobs. This was reflected in the notably high overall gender segregation figures across these industries. Moreover, the very few women working in such male-dominated industries faced a noteworthy amount of inequality in terms of both pay and the location of the occupations they held in the social hierarchy. However, overall, the service sector did not seem to operate in favor of women in Turkey, either. Although the overall occupational gender segregation figure was relatively low, women's disadvantaged position was maintained in the service sector. Women held occupations associated with lower levels of pay, and their unfavorable situation in terms of social stratification was comparable to that observed in some non-service sectors of employment.

The breakdown within the service sector showed that women's share across non-manual, potentially 
Table 4 Overall and vertical occupational gender segregation by industry

\begin{tabular}{|c|c|c|c|c|c|}
\hline & $\begin{array}{l}\text { Vertical segregation } \\
\text { measured by mean } \\
\text { hourly pay }\end{array}$ & $\begin{array}{l}\text { Vertical segregation } \\
\text { measured by mean } \\
\text { monthly pay }\end{array}$ & $\begin{array}{l}\text { Vertical segrega- } \\
\text { tion measured by } \\
\text { CAMSIS }\end{array}$ & $\begin{array}{l}\text { Overall occupa- } \\
\text { tional Segrega- } \\
\text { tion }\end{array}$ & $\begin{array}{l}\text { Share in female } \\
\text { employment }\end{array}$ \\
\hline Mining and quarrying & 0.482 & 0.181 & 0.545 & 0.850 & 0.14 \\
\hline Construction & 0.486 & 0.410 & 0.668 & 0.898 & 1.60 \\
\hline $\begin{array}{l}\text { Electricity, gas and water } \\
\text { supply }\end{array}$ & 0.192 & 0.201 & 0.351 & 0.738 & 0.23 \\
\hline Manufacturing & -0.090 & -0.121 & 0.100 & 0.370 & 23.31 \\
\hline $\begin{array}{l}\text { Agriculture, forestry and } \\
\text { fishery }\end{array}$ & -0.308 & -0.303 & 0.091 & 0.324 & 3.43 \\
\hline Service industry (total) & 0.253 & 0.209 & 0.320 & 0.476 & 71.30 \\
\hline \multicolumn{6}{|l|}{ Service industry breakdown } \\
\hline Wholesale and retail trade & 0.086 & 0.079 & 0.327 & 0.463 & 13.07 \\
\hline Transportation and storage & 0.533 & 0.512 & 0.588 & 0.719 & 1.85 \\
\hline $\begin{array}{l}\text { Accommodation and food } \\
\text { service activities }\end{array}$ & -0.116 & -0.187 & -0.125 & 0.408 & 3.97 \\
\hline $\begin{array}{l}\text { Information and communi- } \\
\text { cation }\end{array}$ & 0.002 & -0.058 & 0.179 & 0.508 & 1.50 \\
\hline $\begin{array}{l}\text { Financial, insurance and real } \\
\text { estate activities }\end{array}$ & 0.071 & 0.068 & 0.090 & 0.269 & 3.91 \\
\hline $\begin{array}{l}\text { Professional, scientific and } \\
\text { technical activities }\end{array}$ & -0.038 & -0.107 & -0.003 & 0.329 & 3.46 \\
\hline $\begin{array}{l}\text { Administrative and support } \\
\text { service activities }\end{array}$ & 0.072 & -0.108 & 0.119 & 0.461 & 5.04 \\
\hline $\begin{array}{l}\text { Public administration and } \\
\text { defense; compulsory } \\
\text { social security }\end{array}$ & 0.103 & 0.030 & 0.320 & 0.567 & 6.43 \\
\hline Education & 0.145 & -0.031 & 0.166 & 0.252 & 15.81 \\
\hline $\begin{array}{l}\text { Human health and social } \\
\text { work activities }\end{array}$ & 0.068 & 0.112 & 0.185 & 0.479 & 10.48 \\
\hline $\begin{array}{l}\text { Arts, entertainment and } \\
\text { recreation }\end{array}$ & 0.131 & 0.156 & 0.156 & 0.416 & 0.42 \\
\hline Other services activities & -0.248 & -0.272 & 0.019 & 0.543 & 2.29 \\
\hline $\begin{array}{l}\text { Activities of households as } \\
\text { employers }\end{array}$ & 0.699 & -0.657 & -0.674 & 0.639 & 3.07 \\
\hline
\end{tabular}

A positive (negative) vertical segregation value indicates woman's disadvantageous (advantageous) position compared to man across the occupations. The greater the absolute index value, the larger the extent of the advantage or disadvantage

highly-ranked service sector industries was still low as compared to that of men; in general, women were segregated into occupations associated with lower levels of pay and social status (Table 4). For example, with the exception of their slight pay advantage in the "Professional, scientific and technical activities" industry, women were the disadvantaged group in terms of both pay and social hierarchy across "Human health and social work activities" and "Financial, insurance and real estate activities", which were likely to be located at the higher end of the social stratification and pay continuum.

On the contrary, some women appeared to hold an advantageous position over men in certain service industriessuch as "Other services activities", "Accommodation and food", and "Activities of households as employers"-which are typically located at the lower end of the pay and social stratification continuum. ${ }^{16}$ Beyond these low-ranked service sector industries, women had a slight pay advantage over men across the manufacturing industry. However, these constituted a small share of total female employment (the last column, Table 4). As a consequence, though both men and women were likely to hold occupations with low pay or social status in these industries, men still outnumbered women across occupations that ranked lower in terms of

\footnotetext{
16 The sector of "Activities of households as employers" includes mostly home-based, domestic activities, such as the production of goods and services for one's own use or for sale. This explains why it is the only industry that is largely dominated by women.
} 
Fig. 7 Overall occupational gender segregation (OS) and the vertical dimension (VS) by public and private sector. Note: A positive (negative) vertical segregation value indicates woman's disadvantageous (advantageous) position compared to man across the occupations. The greater the absolute index value, the larger the extent of the advantage or disadvantage

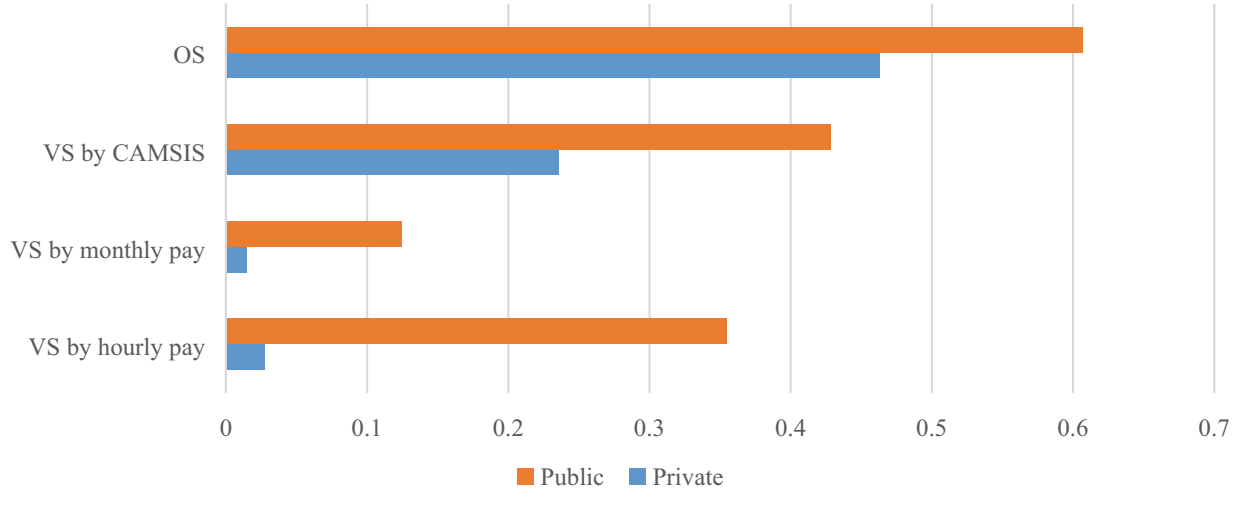

pay or social hierarchy. As a result, women might have artificially appeared to have a better occupational standing. It was, therefore, difficult to gauge whether the labor market was operating in favor of women in these industries or if this was a reflection of the very low number of women who were in employment.

The potential benefit of public sector employment for women in terms of promoting more employment in genderatypical occupations with higher pay/status was not evident for Turkey (Fig. 7). The extent of the vertical dimension was greater in the public sector as compared to the private sector. Overall, the results for Turkey supported the literature suggesting that the expansion of the service or public sectors might not eliminate the inequalities inherent in occupational gender segregation; rather, it might contribute to the gendered division of labor in the public sphere.

\section{Conclusion and Discussion}

This paper attempts to analyze occupational gender segregation in Turkey as a consequence of horizontal and vertical dimensions as suggested by Blackburn et al. (2001). It represents one of the few applications of this approach in a country where the industrialization process is not complete and which has not yet succeeded in promoting women's participation in the labor market and women's incorporation into occupations with better economic and social statuses. Unlike in countries where there is evidence of occupational gender segregation and its components, Turkey's performance in achieving gender equality in employment outcomes has been particularly poor, with traditionalism towards the division of labor manifesting itself both at home and in the labor market. Therefore, the analysis of occupational segregation in Turkey is important for broadening the discussion about the strength of the underlying factors and for shedding light on the potential challenges involved in reducing the gender inequalities inherent in occupational structures across those countries transitioning away from agriculture to manufacturing and services in a more traditional or conservative context.

The results presented in this paper indicate that women are consistently at a disadvantaged position with respect to men and that the extent of inequality is larger when the vertical dimension is measured by a social stratification scale other than pay. In other words, women are more likely to be employed in lower-paid occupations than are men and their chances of being employed in lower-ranked occupations across the social hierarchy are even greater. Moreover, the results reveal a larger horizontal segregation figure compared to vertical segregation.

A larger horizontal component is not peculiar to Turkey. In most of the countries in which the data are available, the horizontal component of segregation tends to be larger than the vertical component (e.g., in Scandinavian countries, Germany, the UK, the USA, and the Netherlands; see Jarman et al. 2012 for country comparisons). That is to say, overall occupational segregation owes more to the differentiation in the occupations that men and women hold. However, unlike the case in Turkey, this differentiation is generally associated with women's employment in occupations that have a better social status than those occupations in which men are employed (although men's pay advantage remains). Whilst this is interpreted as an indication of women's preferences for/aspirations towards certain occupations or their integration into the white-collar sector and professional occupations through the rise of the service sector in industrialized countries, the findings of this paper suggest that these are less likely to be true for Turkey.

Sub-group analyses - in particular, analyses across different educational groups, marital statuses, and industriesprovide important insights into the case in Turkey and its progress towards a less-segregated workforce. Education is regarded as one of the most important determinants of women's participation in the labor market as well as their occupational status. As noted in a number of reports by the European Commission, women's access to higher education through gender-atypical fields of studies might eliminate 
overall occupational gender segregation (for example, see Bettio and Verashchagina 2009; Burchell et al. 2014; Emerek et al. 2003). This might also reduce the pay or social inequalities as more women enter highly-paid, prestigious, previously male-dominated occupations. Indeed, the results for Turkey show a positive effect of education as reflected by lower horizontal segregation amongst highly educated men and women. However, this does not translate into a situation in which highly educated women face less inequality in terms of pay or social status. The unfavorable situation of women in terms of the vertical dimension persists and remains comparable across the different educational groups. Although direct evidence cannot be provided, the results also point to the role of the gendered division of labor in occupational outcomes by displaying a marked difference in the occupations that married women and men hold, which possibly addresses married women's segregation into flexible, family-friendly occupations.

As discussed extensively throughout the paper, the structural transformation and the accompanying shift from manufacturing to services are observed only to a certain extent in Turkey. Although an increase has been seen, the share of services and women's employment within the sector remain considerably lower in Turkey as compared to the EU averages. Moreover, women's representation across industries with potentially highly-ranked service sector jobs is lower than that of men. Given these facts, unlike the case in developed countries, occupational gender segregation figures across the service industries indicate that the favorable effect of the service sector is not evident in Turkey. Actually, whilst the extent of the differentiation in the occupations that men and women hold remains comparable to the figures observed in other industries, such as manufacturing, the inequality associated with occupational segregation in terms of both pay and social status is larger in services. Therefore, the service sector does not appear to challenge the restricted occupational choices available to men and women (distributional inequality, captured by horizontal segregation) to the expected degree, nor does it imply more equal occupational rewards in terms of pay and social status amongst men and women. In parallel, the public sector is associated with a greater level of occupational gender segregation as compared to the private sector, along with a sizable vertical dimension indicating women's disadvantage.

These findings are intuitive in terms of the strength of country-specific elements limiting the potential of structural transformation and the accompanying rise in the service sector in terms of promoting women's progress towards decent occupations. They stress the role of a social and institutional framework that reinforces gender stereotypes and women's subordinate position across the occupational structure. The findings suggest that occupational gender segregation and its vertical and horizontal components should be evaluated in light of multi-layered elements influencing both social and structural transformations and, eventually, women's occupational outcomes. Changes in the industrial structures and their ability to incorporate women into socially and economically attractive jobs, as well as norms, cultural attitudes, the institutional context, and the ways in which they all promote or hinder gender equality are interlinked; together, they influence the extent of occupational gender segregation and its horizontal and vertical dimensions.

These results have important policy implications. Women are segregated into "female occupations" that are undervalued compared to the occupations that men hold. This persists despite the closing of the gap between the educational qualifications of men and women in Turkey. However, education can still be an important policy tool if it is revised in a way that promotes gender equality from the early ages. Moreover, through the adoption of new educational and training programs, women and men can be encouraged to choose gender-atypical fields of study without being exposed to prejudice. This may help reduce occupational gender segregation by making broader occupational choices available to both men and women. However, as shown in this paper, even when highly educated women enter some form of gender "atypical" sectors, they are not as well-rewarded as men are, or they are over-qualified for their jobs. Precisely for this reason, it is essential to monitor the transition between education and the labor market, as gender-discriminatory practices are embedded in labor market institutions, while organizations can be unwilling to hire women or can create barriers to their progress in traditionally male-dominated occupations.

Although unpaid care and domestic work have a fundamental role in reproducing the labor force, gender disparity in paid/unpaid work remains an important limit for women's access to favorable paid employment in which their contributions are rightfully valued. In order to incorporate more women in decent workplaces, it is important to transform the attitudes on responsibilities, and encourage more men to take up domestic and unpaid care activities. In this regard, work and family reconciliation policies that mainly rely on women's inactivity should be challenged. Introducing a comprehensive paternity leave provision, along with accessible and affordable childcare and care for the elderly have a vital role in transforming gender roles and creating equal opportunities for men and women in the labor market.

Overall, the findings suggest that occupational gender segregation and the associated inequalities can only be eliminated through a multidimensional, coordinated approach that enables legal reforms, and social and labor market institutions to function together to promote gender equality and challenge gender stereotypes and discriminatory practices. 
Acknowledgements I would like to thank the editor, two anonymous referees, Sara Connolly, Susan Long, Kerry Papps, Zaki Wahhaj and Okan Yilmaz for their advice and feedback.

Funding This study was not funded.

\section{Compliance with Ethical Standards}

Conflicts of interest The author declares no conflict of interest.

Ethical Approval This article does not contain any studies with human participants or animals performed by the author.

Open Access This article is licensed under a Creative Commons Attribution 4.0 International License, which permits use, sharing, adaptation, distribution and reproduction in any medium or format, as long as you give appropriate credit to the original author(s) and the source, provide a link to the Creative Commons licence, and indicate if changes were made. The images or other third party material in this article are included in the article's Creative Commons licence, unless indicated otherwise in a credit line to the material. If material is not included in the article's Creative Commons licence and your intended use is not permitted by statutory regulation or exceeds the permitted use, you will need to obtain permission directly from the copyright holder. To view a copy of this licence, visit http://creativecommons.org/licenses/by/4.0/.

\section{Appendix}

See Table 5 .

Table 5 Descriptive statistics for the demographic variables and the share of the public-sector employment

\begin{tabular}{|c|c|c|c|c|c|c|c|c|}
\hline \multirow[t]{2}{*}{ Occupations } & \multicolumn{2}{|l|}{$\mathrm{Age}^{\mathrm{a}}$} & \multicolumn{2}{|c|}{ Education $^{\mathrm{a}}$} & \multicolumn{2}{|l|}{ Married $^{\text {b }}$} & \multicolumn{2}{|c|}{ Public-sector ${ }^{b}$} \\
\hline & Women & Men & Women & Men & Women & Men & Women & Men \\
\hline 11-Legislators and Senior officials & 5.40 & 6.95 & 5.50 & 3.76 & 71.22 & 94.78 & 76.16 & 91.41 \\
\hline 12-Corporate Managers & 4.77 & 5.51 & 5.69 & 5.38 & 51.17 & 84.82 & 31.04 & 41.91 \\
\hline 13-Managers of small enterprises & 4.41 & 4.86 & 4.86 & 3.86 & 36.49 & 79.68 & 3.41 & 2.55 \\
\hline 21-Physical, Mathematical and Engineering science & 4.09 & 4.45 & 5.99 & 5.98 & 45.75 & 58.13 & 34.97 & 26.23 \\
\hline 22-Life science and Health professionals & 4.65 & 5.18 & 6.00 & 5.98 & 66.83 & 74.74 & 82.33 & 82.51 \\
\hline 23-Teaching professionals & 4.37 & 5.03 & 5.98 & 5.99 & 64.76 & 77.51 & 84.47 & 88.15 \\
\hline 24-Other professionals & 3.97 & 4.83 & 5.92 & 5.62 & 48.09 & 82.49 & 32.10 & 77.33 \\
\hline 31-Physical and Engineering Associate Professionals & 3.75 & 4.61 & 4.23 & 4.69 & 50.61 & 75.09 & 14.71 & 21.13 \\
\hline 32-Life science and Health Associate Professional & 3.93 & 4.31 & 5.59 & 5.03 & 66.86 & 69.55 & 73.33 & 52.86 \\
\hline 33-Teaching Associate Professionals & 3.54 & 5.90 & 4.75 & 5.06 & 40.74 & 75.05 & 34.63 & 25.10 \\
\hline 34-Other Associate Professionals & 3.91 & 4.78 & 5.12 & 4.51 & 42.48 & 73.56 & 19.55 & 28.54 \\
\hline 41-Office clerks & 3.79 & 4.71 & 4.79 & 4.49 & 43.01 & 71.14 & 26.29 & 36.16 \\
\hline 42-Customer service clerks & 3.23 & 4.48 & 4.89 & 4.46 & 35.09 & 62.85 & 15.25 & 27.25 \\
\hline 51-Personal and Protective Services workers & 4.39 & 4.17 & 3.07 & 3.61 & 57.02 & 68.42 & 8.66 & 28.37 \\
\hline 52-Models, Salesperson and Demonstrators & 2.89 & 3.83 & 3.92 & 3.46 & 25.36 & 57.87 & 0.00 & 0.13 \\
\hline 61-Market oriented skilled agricultural and fishery workers & 5.26 & 5.09 & 1.98 & 2.37 & 72.47 & 79.52 & 2.04 & 10.34 \\
\hline 62-Subsistence agricultural and fishery workers & & 6.00 & & 2.00 & & 100.00 & & 0.00 \\
\hline 71-Extraction and building trades workers & 3.34 & 4.46 & 2.77 & 2.67 & 54.65 & 76.16 & 0.00 & 6.14 \\
\hline 72-Metal, machinery and related trades workers & 3.38 & 4.08 & 3.40 & 3.19 & 46.86 & 69.18 & 1.34 & 6.32 \\
\hline 73-Precision, handicraft and related trades workers & 3.84 & 3.78 & 3.17 & 3.05 & 65.10 & 59.74 & 5.73 & 2.57 \\
\hline 74-Other craft and related trades workers & 3.53 & 3.93 & 2.45 & 2.63 & 45.17 & 69.27 & 1.34 & 1.02 \\
\hline 81-Stationary plant and related operators & 3.82 & 4.40 & 2.90 & 3.26 & 56.92 & 78.09 & 0.00 & 5.09 \\
\hline 82-Machine operators and assemblers & 3.45 & 3.88 & 2.67 & 2.92 & 45.16 & 70.89 & 0.66 & 1.12 \\
\hline 83-Drivers and mobile plant operators & 4.42 & 5.33 & 2.83 & 2.83 & 55.96 & 88.44 & 12.95 & 15.75 \\
\hline 91-Sales and Services Elementary Occupations & 5.03 & 4.96 & 2.39 & 2.61 & 73.95 & 79.52 & 4.35 & 16.37 \\
\hline 92-Agricultural, fishery and related laborers & 4.26 & 4.53 & 1.84 & 2.14 & 58.84 & 70.05 & 0.28 & 2.47 \\
\hline 93-Laborers in mining, construction, manufacturing and transport & 3.50 & 4.19 & 2.63 & 2.69 & 54.46 & 71.19 & 0.00 & 3.78 \\
\hline Total & & & & & 54.52 & 74.99 & 29.60 & 23.49 \\
\hline
\end{tabular}

${ }^{a}$ in mean values. Age is a categorical variable which takes values from 1 to 10 for the age groups $15-19 ; 20-24 ; 25-29 ; 30-34$; 35-39; 40-44; $45-49 ; 50-54 ; 55-59 ; 60-64$ respectively. Education is a categorical variable coded as $1=$ literate but do not have a diploma, $2=$ primary school, $3=$ secondary school, $4=$ high school, $5=$ high school/vocational high school, $6=$ higher education

${ }^{\mathrm{b}}$ Values are in percentages 


\section{References}

Akbulut, R. (2011). Sectoral changes and the increase in women's labor force participation. Macroeconomic Dynamics, 15(2), 240-264. https://doi.org/10.1017/S1365100510000040.

Anker, R. (1998). Gender and jobs, sex segregation of occupations in the world. Geneva: International Labour Office.

Anker, R., Melkas, H., \& Korten, A. (2003). Gender-based occupational segregation in the 1990's. International Labor Office Declaration Working Paper no. 16. Retrieved from https://www.oit. org/wcmsp5/groups/public/---ed_norm/---declaration/documents/ publication/wcms_decl_wp_18_en.pdf.

Berik, G., Rodgers, Y. V., \& Zveglich, J. E. (2004). International trade and gender wage discrimination: Evidence from East Asia. Review of Development Economics, 8(2), 237-254. https://doi.org/10.11 11/j.1467-9361.2004.00230.x.

Bettio, F., \& Verashchagina, A. (2009). Gender segregation in the labour market. Root causes, implications and policy responses in the EU. Report by the European Commission's expert group on gender and employment issues, european communities, Luxembourg: Publications Office of the European Union. Retrieved from https://op.europa.eu/en/publication-detail/-/publication/39e67 b83-852f-4f1e-b6a0-a8fbb599b256/language-en/format-PDF/ source-search.

Blackburn, R. M. (2009). Measuring occupational segregation and its dimensions of inequality and difference. Cambridge Studies in Social Research no.12. Retrieved from https://www.sociology. cam.ac.uk/system/files/documents/cs12.pdf.

Blackburn, R. M., \& Jarman, J. (2006). Gendered occupations. International Sociology, 21(2), 289-315. https://doi.org/10.1177/02685 80906061380.

Blackburn, R. M., Brooks, B., \& Jarman, J. (2001). The vertical dimension of occupational segregation. Work, Employment and Society, 15(3), 511-538. https://doi.org/10.1177/09500170122119138.

Bottero, W. (2005). Interaction distance and the social meaning of occupations. The Sociological Review, 53(2), 56-72. https://doi. org/10.1111/j.1467-954X.2005.00572.x.

Bozçağa, T. (2013). Women and the welfare state regime of Turkey. Turkish Policy Quarterly, 11(4), 177-188.

Buğra, A., \& Yakut-Cakar, B. (2010). Structural change, the social policy environment and female employment in Turkey. Development and Change, 41(3), 517-538. https://doi.org/10.111 1/j.1467-7660.2010.01643.x.

Burchell, B. J. (1996). Gender segregation, size of workplace and the public sector. Gender, Work \& Organization, 3(4), 227-235. https ://doi.org/10.1111/j.1468-0432.1996.tb00062.x.

Burchell, B. J., Hardy, W., Rubery, J., \& Smith, M. (2014). A new method to understand occupational gender segregation in European Labour Markets. Retrieved from https://publications.europ a.eu/en/publication-detail/-/publication/2f6938c9-86ac-11e5b8b7-01aa75ed71a1/language-en.

Charles, M. (1990). Occupational sex segregation: A log linear analysis of patterns in 25 industrial countries. Stanford, CA: Stanford University.

Charles, M. (1992). Cross-national variation in occupational sex segregation. American Sociological Review, 57(4), 483-502. https:// doi.org/10.2307/2096096.

Charles, M. (2003). Deciphering sex segregation: Vertical and horizontal inequalities in ten national labor markets. Acta Sociologica, 46(4), 267-287. https://doi.org/10.1177/0001699303464001.

Connolly, S., \& Gregory, M. (2008). Moving down: Women's parttime work and occupational change in Britain 1991-2001. The Economic Journal, 118(526), 52-76. https://doi.org/10.111 1/j.1468-0297.2007.02116.x.
Dayığlu, M., \& Kırdar, M. G. (2010). Determinants of and trends in labor force participation of women in Turkey (English). Welfare and social policy analytical work program; working paper no. 5 . Washington DC: World Bank. Retrieved from https://documents. worldbank.org/curated/en/466591468316462301/Determinantsof-and-trends-in-labor-force-participation-of-women-in-Turkey.

Dedeoğlu, S. (2010). Visible hands-Invisible women: Garment production in Turkey. Feminist Economics, 16(4), 1-32. https://doi. org/10.1080/13545701.2010.530606.

Devine, F. (1994). Segregation and supply: Preferences and plans among 'self-made' women. Gender, Work \& Organization, 1(2), 94-109. https://doi.org/10.1111/j.1468-0432.1994.tb00009.x.

Dolado, J. J., Felgueroso, F., \& Jimeno, J. F. (2003). Where do women work?: Analysing patterns in occupational segregation by gender. Annales D'Économie Et De Statistique. https://doi. org/10.2307/20079056.

Duncan, O. D., \& Duncan, B. (1955). A methodological analysis of segregation indexes. American Sociological Review, 20(2), 210 217. https://doi.org/10.2307/2088328.

Elson, D. (1999). Labour markets as gendered institutions: Equality, efficiency and empowerment issues. World Development, 27(3), 611-627. https://doi.org/10.1016/S0305-750X(98)00147-8.

Emerek, R., Figueiredo, H., González, P., Gonäs, L., \& Rubery, J. (2003). Indicators on gender segregation. Research Center on Industrial, Labour and Managerial Economics. Retrieved from https://core.ac.uk/download/pdf/6379134.pdf.

Fan, C. S., \& Lui, H.-K. (2003). Structural change and the narrowing gender gap in wages: theory and evidence from Hong Kong. Labour Economics, 10(5), 609-626. https://doi.org/10.1016/ S0927-5371(03)00032-0.

Galor, O., \& Weil, D. N. (1996). The gender gap, fertility, and growth. American Economic Review, 86(3), 374-387.

Ganzeboom, H. B. G., De Graaf, P. M., \& Treiman, D. J. (1992). A standard international socio-economic index of occupational status. Social Science Research, 21(1), 1-56. https://doi. org/10.1016/0049-089x(92)90017-B.

Gedikli, C. (2014). Exploring the extent of inequality associated with occupational gender segregation in Turkey. Retrieved from https ://www.camsis.stir.ac.uk/versions.html\#Turkey.

Goldin, C. (1995). The U-shaped female labor force function in economic development and economic history. In T. P. Schultz (Ed.), Investment in women's human capital and economic development (pp. 61-90). Chicago: University of Chicago Press.

Goldin, C. (2006). The quiet revolution that transformed women's employment, education, and family. American Economic Review, 96(2), 1-21.

Greenwood, J., Seshadri, A., \& Yorukoglu, M. (2005). Engines of liberation. The Review of Economic Studies, 72(1), 109-133. https ://doi.org/10.1111/0034-6527.00326.

Günlük-Senesen, G., \& Özar, S. (2001). Gender-based occupational segregation in the Turkish banking sector. In M. Cinar (Ed.), The economics of women and work in the middle East and North Africa. Research in middle east economics (Vol. 4, pp. 247-267). Bingley: Emerald Group Publishing Limited.

Heathcote, J., Storesletten, K., \& Violante, G. L. (2010). The macroeconomic implications of rising wage inequality in the United States. Journal of Political Economy, 118(4), 681-722. https:// doi.org/10.1086/656632.

Hesmondhalgh, D., \& Baker, S. (2015). Sex, gender and work segregation in the cultural industries. The Sociological Review, 63(1), 23-36. https://doi.org/10.1111/1467-954X.12238.

İlkkaracan, İ. (2012). Why so few women in the labor market in Turkey? Feminist Economics, 18(1), 1-37. https://doi.org/10.1080/13545 701.2011 .649358 . 
Turkish Statistical Institute (TurkStat). (2010). Population censuses. Retrieved from https://www.turkstat.gov.tr/PreTablo. do?alt_id=1047.

Jarman, J., Blackburn, R. M., \& Racko, G. (2012). The dimensions of occupational gender segregation in industrial countries. Sociology, 46(6), 1003-1019. https://doi.org/10.1177/0038038511435063.

Kan, M. Y. (2008). Does gender trump money? Housework hours of husbands and wives in Britain. Work, Employment and Society, 22(1), 45-66. https://doi.org/10.1177/0950017007087416.

Karmel, T., \& Maclachlan, M. (1988). Occupational sex segregationIncreasing or decreasing? Economic Record, 64(3), 187-195. https://doi.org/10.1111/j.1475-4932.1988.tb02057.x.

Kaya Bahçe, S. A., \& Memiş, E. (2013). Estimating the impact of the 2008-09 economic crisis on work time in Turkey. Feminist Economics, 19(3), 181-207. https://doi.org/10.1080/13545 701.2013 .786182 .

Kongar, E., \& Memiş, E. (2017). Gendered patterns of time use over the life cycle: Evidence from Turkey. In R. Connelly \& E. Kongar (Eds.), Gender and time use in a global context: The economics of employment and unpaid labor (pp. 373-406). New York: Palgrave MacMillan.

Lambert, P. S., \& Prandy, K. (2018). CAMSIS project webpages: Cambridge Social Interaction and Stratification Scales, Retrieved November 25, 2019, from https://www.camsis.stir.ac.uk.

Mandel, H., \& Semyonov, M. (2006). A welfare state paradox: State interventions and womens employment opportunities in 22 countries. American Journal of Sociology, 111(6), 1910-1949. https ://doi.org/10.1086/499912.

Mehra, R., \& Gammage, S. (1999). Trends, countertrends, and gaps in women's employment. World Development, 27(3), 533-550. https ://doi.org/10.1016/S0305-750X(98)00148-X.

Menon, N., \& Rodgers, Y. V. (2009). International trade and the gender wage gap: New evidence from India's manufacturing sector. World Development, 37(5), 965-981. https://doi.org/10.1016/j. worlddev.2008.09.009.

Ngai, L. R., \& Petrongolo, B. (2017). Gender gaps and the rise of the service economy. American Economic Journal: Macroeconomics, 9(4), 1-44. https://doi.org/10.1257/mac.20150253.

Olivetti, C., \& Petrongolo, B. (2014). Gender gaps across countries and skills: Demand, supply and the industry structure. Review of Economic Dynamics, 17(4), 842-859. https://doi.org/10.1016/j. red.2014.03.001.

Özbilgin, M. F., \& Healy, G. (2004). The gendered nature of career development of university professors: The case of Turkey. Journal of Vocational Behavior, 64(2), 358-371. https://doi.org/10.1016/j. jvb.2002.09.001.

Özbilgin, M. F., \& Woodward, D. (2004). 'Belonging' and 'Otherness': Sex equality in banking in Turkey and Britain. Gender, Work \& Organization, 11(6), 668-688. https://doi.org/10.111 1/j.1468-0432.2004.00254.x.

Razavi, S., Arza, C., Braunstein, E., Cook, S. \& Goulding, K. (2012). Gendered impacts of globalization: Employment and social protection. United Nations Research Institute for Social Development (UNRISD) Research Paper no. 3. Retrieved from https://www. unrisd.org/unrisd/website/document.nsf/(httpPublications)/6E16D 1DC33F5D82BC12579D000478859?OpenDocument.

Rendall, M. (2018). Female market work, tax regimes, and the rise of the service sector. Review of Economic Dynamics, 28, 269-289. https://doi.org/10.1016/j.red.2017.09.002.
Reskin, B. F., \& Roos, P. А. (1990). Job queues, gender queues: Explaining women's inroads into male occupations. Philadelphia: Temple University Press.

Rich, J., \& Palaz, S. (2008). Why has occupational sex segregation in Turkey increased since 1975? LABOUR, 22(1), 185-218. https:// doi.org/10.1111/j.1467-9914.2008.000408.x.

Rubery, J., \& Fagan, C. (1995). Gender segregation in societal context. Work, Employment and Society, 9(2), 213-240. https://doi. org/10.1177/095001709592001.

Sağlamer, G., Tan, M., Çebi, P. D., Çağlayan, H., Gümüşoğlu, N. K., Poyraz, B., et al. (2018). Gendered patterns of higher education in Turkey: Advances and challenges. Women's Studies International Forum, 66, 33-47. https://doi.org/10.1016/j.wsif.2017.11.002.

Semuonov, M., \& Jones, F. L. (1999). Dimensions of gender occupational differentiation in segregation and inequality: A crossnational analysis. Social Indicators Research, 46(2), 225-247. https://doi.org/10.1023/a:1006839220017.

Seron, C., Silbey, S., Cech, E., \& Rubineau, B. (2016). Persistence is cultural: Professional socialization and the reproduction of sex segregation. Work and Occupations, 43(2), 178-214. https://doi. org/10.1177/0730888415618728.

Sevilla-Sanz, A., Gimenez-Nadal, J. I., \& Fernández, C. (2010). Gender roles and the division of unpaid work in Spanish households. Feminist Economics, 16(4), 137-184. https://doi.org/10.1080/13545 701.2010 .531197$.

Standing, G. (1999). Global feminization through flexible labor: A theme revisited. World Development, 27(3), 583-602. https://doi. org/10.1016/S0305-750X(98)00151-X.

Stewart, A., Prandy, K., \& Blackburn, R. M. (1980). Social Stratification and Occupations. London: MacMillan.

Taymaz, E. (2010). Growth, employment, skills and female labor force. State Planning Organization of the Republic of Turkey and World Bank Welfare and Social Policy Analytical Work Program Working Paper no. 6. Retrieved from https://siteresources.worldbank. org/INTTURKEY/147254-1268836253913/22521459/Growt hAndEmploymentInTurkey.pdf.

TurkStat. Household Labor Force Surveys. (2010-2018). Retrieved from https://www.turkstat.gov.tr/PreTablo.do?alt_id=1007.

TurkStat. Marriage Statistics. (2010). Retrieved from https://www.turks tat.gov.tr/PreTablo.do?alt_id=1068.

Publisher's Note Springer Nature remains neutral with regard to jurisdictional claims in published maps and institutional affiliations.

Cigdem Gedikli is a Lecturer and Researcher in School of Management, Swansea University. She completed a Ph.D. at Norwich Business School, University of East Anglia in 2016 and worked as a Senior Research Associate on the Work, Learning and Wellbeing evidence programme for the Economic and Social Research Council funded What Works Wellbeing Centre. Her research interests center on labor economics, economics of gender, and wellbeing. She is particularly interested in analyzing the relationships between unequal practices in the labor markets, decent work and the associated impact on social and economic wellbeing. 